\title{
KARAKTERISTIK GAMBUT BERDASARKAN ANALISIS GEOKIMIA DAN PETROGRAFI ORGANIK DI KABUPATEN INDRAGIRI HILIR, PROVINSI RIAU
}

\section{THE CHARACTERISTICS OF PEAT BASED ON ANALYSIS OF ORGANIC GEOCHEMISTRY AND PETROGRAPHY IN INDRAGIRI HILIR DISTRICT, RIAU PROVINCE}

\author{
Priyono dan Sigit A. Wibisono \\ Pusat Sumber Daya Mineral, Batubara dan Panas Bumi \\ pri_rck@yahoo.com
}

\begin{abstract}
ABSTRAK
Gambut merupakan salah satu sumber energi alternatif. Luas lahan gambut Indonesia menempati peringkat keempat di dunia, yaitu sekitar 26 juta hektar. Pemanfaatan dan pengelolaan lahan gambut di Indonesia masih sebatas untuk lahan pertanian dan perkebunan saja, sedangkan pemanfaatan gambut sebagai sumber energi masih belum dilakukan. Penelitian ini bertujuan untuk mengetahui karakteristik dan kualitas gambut sebagai salah satu sumber energi di Kabupaten Indragiri Hilir, Provinsi Riau. Analisis geokimia dan petrografi organik dilakukan terhadap 17 perconto gambut di daerah penelitian. Hasil analisis menunjukkan bahwa gambut di daerah penelitian mempunyai nilai kalori $3.098 \mathrm{kal} / \mathrm{g}$ s.d. 5.178 $\mathrm{kal} / \mathrm{g}$ dan termasuk dalam tipe gambut ombrogenus serta diendapkan pada lingkungan yang dipengaruhi pasang surut air (telmatik). Pembentuk gambut didominasi oleh tetumbuhan berbatang lunak (marginal aquatic/herbaceous).
\end{abstract}

Kata kunci: energi, gambut, ombrotropik, geokimia organik dan petrografi organik

\section{ABSTRACT}

Peat is one of alternative energy sources. Indonesia's peatland area is recognized in the world of approximately 26 million hectares. The utilization and management of peat moss in Indonesia is still limited to agricultural and plantation land only, while peat utilization as an energy source is still not applied yet. This study aims to determine the characteristics and potential of peat deposits as one source of energy in Indragiri Hilir Regency, Riau Province. Analyses of organic geochemistry and organic petrography were conducted on 17 peat samples in the study area. The results show that peat in the study area has a calorific value of 3,098-5,178 cal/g and is included in ombrogenous peat type and deposited in tidal environments (telmatic). Peat-forming growth is dominated by soft trunk (aquatic marginal/herbaceous).

Keywords: source, peat, ombrotrophic, organic geochemistry and organic petrography

\section{PENDAHULUAN}

Gambut merupakan sedimen yang mempunyai kandungan bahan organik tinggi, berasal dari akumulasi sisa-sisa tetumbuhan yang mengalami humifikasi dalam kondisi tanpa udara, umumnya berada di bawah air, mempunyai kandungan air $\geq 75 \%$ berat dan kandungan karbon $\leq 60 \%$ berat dalam kondisi kering, bersifat tidak padat serta dapat terbakar (Angayana, 2002)

Gambut mempunyai potensi sebagai salah satu sumber energi alternatif. Komponen organik dalam gambut yang berupa karbon merupakan komponen yang mempunyai peranan penting dalam pemanfaatan dan pengelolaan gambut sebagai sumber energi. 
Menurut Moore (1987), gambut dapat dibedakan menjadi dua tipe berdasarkan lingkungan pembentuknya, yaitu: ombrogenus dan topogenus. Tipe ombrogenus merupakan gambut yang terbentuk pada lingkungan yang hanya dipengaruhi oleh air hujan, sehingga miskin mineral dan unsur hara, sedangkan topogenus adalah gambut yang terbentuk pada daerah yang dipengaruhi oleh pasang surut air sungai atau laut, sehingga kaya akan mineral dan unsur hara lainnya. Umumnya, tingkat kesuburan gambut topogenus lebih subur dibandingkan gambut ombrogenus, karena nutrisi yang didapatkan berasal dari air sungai atau air laut yang merupakan tempat hidup berbagai jenis makhluk yang hidup di lingkungan air.

Berdasarkan data Agus dan Subiksa (2008), Iahan gambut di dunia mencapai 420 juta hektar yang tersebar di beberapa negara, antara lain, Kanada, Rusia, Amerika Serikat, Indonesia, Finlandia, Swedia, Cina, Irlandia. Indonesia menempati peringkat keempat dengan luas lahan gambut mencapai 26 juta hektar atau sekitar $6,19 \%$ dari total jumlah luas lahan gambut di dunia (Tabel 1).

Sebagian besar lahan gambut di Indonesia tersebar di Pulau Sumatra dan Pulau Kalimantan. Pemanfaatan gambut di Indonesia saat ini masih sebatas untuk lahan pertanian dan perkebunan, sedangkan pemanfaatan gambut sebagai sumber energi masih belum dilakukan. Menurut Ritung dkk. (2011), Sumatra mempunyai lahan gambut terluas, yaitu 6.436.649 hektar atau $24,76 \%$ dari luas lahan gambut Indonesia (Agus dan Subiksa, 2008), sedangkan menurut hasil kegiatan penyelidikan dan kajian yang telah dilakukan oleh Badan Geologi (2017) menyatakan bahwa luas lahan gambut Pulau Sumatra yang berpotensi menghasilkan energi adalah sebesar 1.498 .833 atau sekitar $23,29 \%$ total lahan gambut di Pulau Sumatra.
Tabel 1. Luas lahan gambut dunia (Agus dan Subiksa, 2008).

\begin{tabular}{lr}
\hline \multicolumn{2}{c}{ Luas Lahan Gambut Dunia } \\
\hline \multicolumn{2}{c}{ Negara } \\
\hline Kanada & 170,0 \\
\hline Rusia & 150,0 \\
\hline Amerika Serikat & 40,0 \\
\hline Indonesia & 26,0 \\
\hline Finlandia & 10,0 \\
\hline Swedia & 7,0 \\
\hline Cina & 3,5 \\
\hline Irlandia & 1,2 \\
\hline Lain-lain & 12,3 \\
\hline Total & 420,0 \\
\hline
\end{tabular}

Maksud penelitian ini adalah melakukan analisis geokimia dan petrografi organik terhadap beberapa perconto gambut yang bertujuan untuk mengetahui karakteristik gambut di Kabupaten Indragiri Hilir, Provinsi Riau.

Daerah penelitian secara administratif terletak di Kabupaten Indragiri Hilir, Provinsi Riau, sedangkan berdasarkan batas koordinat geografis terletak pada 102 $35^{\prime} 00^{\prime \prime}-103^{\circ} 50^{\prime} 00^{\prime \prime}$ BT dan $00^{\circ} 30^{\prime} 00^{\prime \prime}-00^{\circ} 55^{\prime} 00^{\prime \prime}$ LS (Gambar 1).

\section{GEOLOGI}

Daerah penelitian termasuk dalam peta geologi Lembar Rengat yang merupakan bagian dari tektonik regional Pulau Sumatra (Gambar 2).

Batuan tertua yang terdapat pada Lembar Rengat adalah batuan berumur Pra-Tersier, yang tersingkap di sekitar Kepulauan Karimun, terletak di sebelah timur Kabupaten Pelalawan, terdiri dari batuan metakuarsit, granit, dan tufa, sedangkan batuan yang berumur Tersier umumnya terdiri dari batuan sedimen yang terdiri dari batupasir, batulempung, batubara, dan sebagainya. Pada Zaman Kuarter diendapkan Formasi Minas berumur Plistosen Bawah, Aluvium Tua berumur Plistosen Atas, dan Aluvium berumur Holosen. Formasi Minas bagian atas di beberapa tempat diketahui sebagai 


\section{MAKALAH ILMIAH}

Formasi Kerumutan, sedangkan Aluvium terdiri dari endapan pasir, lempung, sisa-sisa tumbuhan, dan gambut yang diendapkan dalam lingkungan paralik sampai fluvial (Suwarna dkk., 1995).
Batuan yang terdapat di daerah penelitian hanya berupa aluvium berumur Holosen, yang hampir seluruhnya didominasi oleh gambut (Suwarna dkk., 1995; Tabel 2).

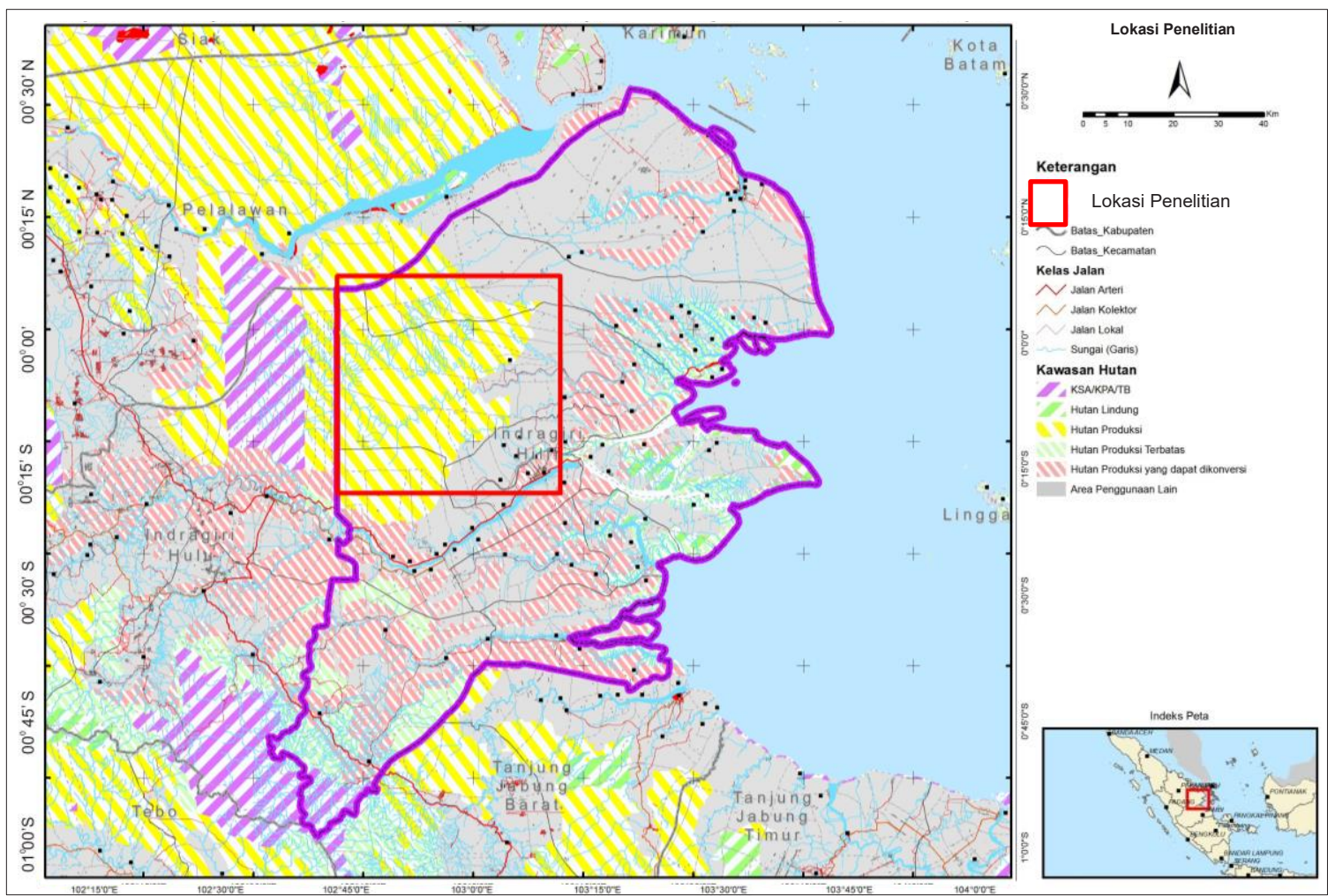

Gambar 1. Lokasi daerah penelitian

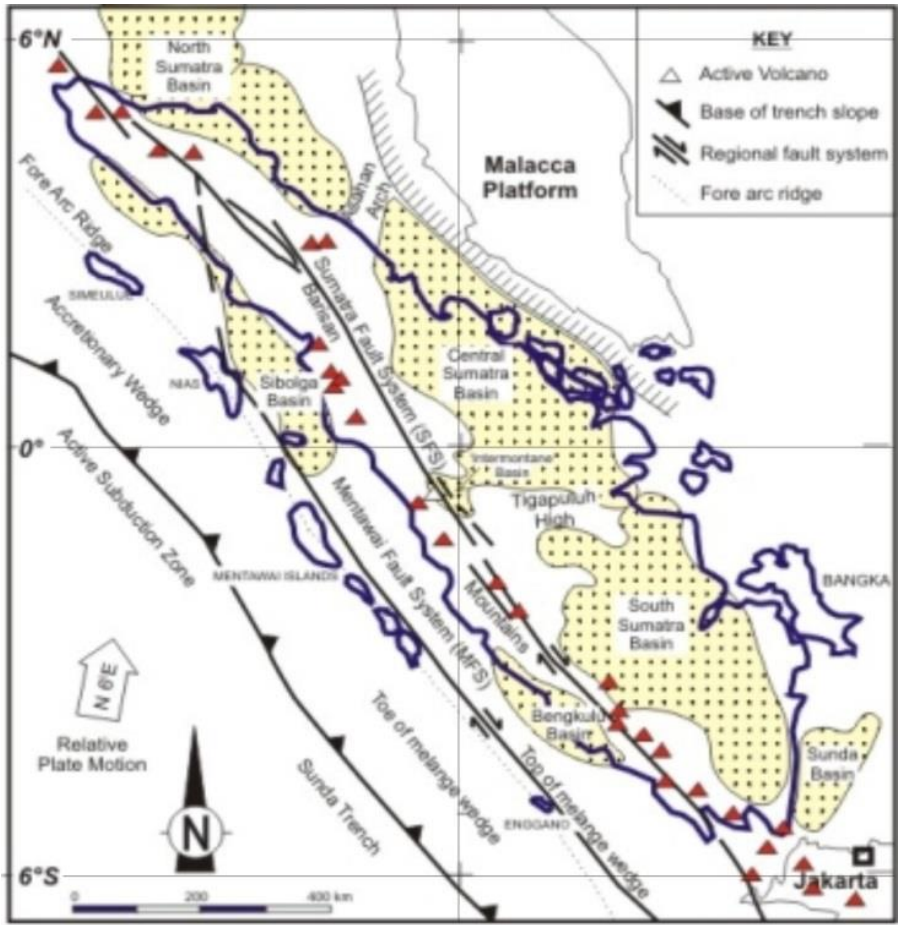

Gambar 2. Tektonik Regional Pulau Sumatra (de Coster, 1974). 


\section{MAKALAH ILMIAH}

Tabel 2. Stratigrafi endapan gambut di daerah penelitian (Suwarna dkk., 1995)

\begin{tabular}{ccclc}
\hline Zaman & Kala & Formasi & \multicolumn{1}{c}{ Litologi } & $\begin{array}{c}\text { Lingkungan } \\
\text { Pengendapan }\end{array}$ \\
\hline \multirow{3}{*}{ Kuarter } & Holosen & Aluvium & $\begin{array}{l}\text { Gambut, sisa tumbuhan, } \\
\text { lempung, lanau, kerikil } \\
\text { kecil, dan koral }\end{array}$ & Paralik \\
\cline { 2 - 5 } & $\begin{array}{c}\text { Plistosen } \\
\text { Atas }\end{array}$ & $\begin{array}{c}\text { Aluvium } \\
\text { Tua }\end{array}$ & $\begin{array}{l}\text { Sisa tumbuhan, lempung, } \\
\text { lanau, pasir, dan kerikil } \\
\text { lempungan }\end{array}$ & Paralik - Fluvial \\
\cline { 2 - 5 } & $\begin{array}{c}\text { Plistosen } \\
\text { Bawah }\end{array}$ & Minas & $\begin{array}{l}\text { Batulumpur lunak, } \\
\text { berurat kaolin, batulanau, } \\
\text { pasir, dan kerikil }\end{array}$ & Fluvial \\
\hline \multirow{2}{*}{ Tersier } & Pliosen & Petani & $\begin{array}{l}\text { Batulumpur karbonan } \\
\text { bioturbit, berhorizon } \\
\text { tufaan, dan lapisan } \\
\text { batubara }\end{array}$ & Darat - Laut \\
\hline
\end{tabular}

\section{METODE PENELITIAN}

Penelitian ini menggunakan data yang berasal dari 17 perconto gambut hasil kegiatan penyelidikan lapangan Pusat Sumber Daya Mineral Batubara dan Panas Bumi di Kabupaten Indragiri Hilir, Provinsi Riau. Metodologi yang digunakan untuk mengetahui karakteristik dan kualitas gambut adalah dengan melakukan analisis geokimia dan petrografi organik. Proses analisis geokimia dan petrografi organik dilakukan di Laboratorium Pusat Sumber Daya Mineral dan Batubara Bandung.

Analisis geokimia organik meliputi analisis proksimat dan ultimat. Analisis proksimat bertujuan untuk mengetahui kandungan air bebas (free moisture), air total (total moisture), air terikat (moisture), zat terbang (volatile matter), karbon tertambat (fixed carbon), sulfur (sulphur), abu (ash), dan nilai kalori (calorific value). Analisis ultimat bertujuan untuk mengidentifikasi unsur-unsur kimia yang terdapat pada gambut, yang meliputi karbon, oksigen, hidrogen, sulfur, dan nitrogen. Fokus kedua analisis ini adalah untuk mengetahu peringkat, tipe dan kandungan mineral gambut di daerah penelitian. Hasil kedua analisis ini dinyatakan dalam satuan persen.

Seluruh perconto yang dianalisis di laboratorium menggunakan tiga basis, yaitu: adb (air dried base), daf (dry ash free), dan ar (as received). Adb adalah kondisi perconto yang mempunyai kadar kelembapan yang mirip dengan kelembaban udara sekitar, daf merupakan kondisi perconto yang diasumsikan kelembapan dan kadar abu telah dihilangkan. Ar adalah keadaan perconto yang dianalisis mempunyai kondisi yang sama pada saat diterima di laboratorium. Kedua analisis tersebut menggunakan alat Leco CHN 2000, Leco TGA 601, dan Leco SC 632.

Analisis petrografi organik terdiri atas pengukuran komposisi maseral dan mineral serta reflektansi vitrinit. Analisis tersebut menggunakan mikroskop Carl Zeiss Axioplan yang terhubung dengan komputer yang didukung alat penghitung digital. Analisis ini bertujuan untuk mengidentifikasi lingkungan tempat terbentuknya gambut atau lingkungan pengendapan gambut.

\section{HASIL}

\section{Analisis Proksimat Gambut}

Hasil analisis proksimat (Tabel 3) menunjukkan bahwa kandungan air bebas dan air total pada 17 perconto berkisar $81,30 \%$ s.d. $89,61 \%$ (ar).

Hasil analisis nilai kalori terhadap 17 perconto gambut berkisar $3.098 \mathrm{kal} / \mathrm{g}$ s.d. 
$5.178 \mathrm{kal} / \mathrm{g}$. Terdapat tiga perconto yang mempunyai nilai kalori kurang dari 4.000 $\mathrm{kal} / \mathrm{g}$, yaitu perconto GTB-05, GTC-07, dan GTC-03. Hal ini disebabkan karena kandungan abu pada ketiga perconto tersebut cenderung lebih besar dibandingkan perconto lainnya.

Kadar sulfur pada 17 perconto gambut relatif rendah, berkisar $0,20 \%$ s.d. $1,03 \%$. Kandungan sulfur yang relatif rendah berasal dari material tumbuhan asal pembentuk gambut dan tidak dipengaruhi oleh air laut (Chou, 2012).

Menurut Chou (2012), kandungan sulfur dalam batubara secara umum dapat digunakan sebagai salah satu indikator lingkungan pengendapan batubara. Selain itu, Chou (2012) mengelompokkan kandungan sulfur dalam batubara menjadi tiga kelompok, yaitu rendah $(<1 \%)$, sedang $(1-3 \%)$, dan tinggi $(>3 \%)$.

\section{Analisis Ultimat Gambut}

Analisis ultimat dilakukan terhadap 17 perconto gambut pada daerah penelitian (Tabel 4). Hasil analisis tersebut menunjukkan nilai unsur karbon, hidrogen, nitrogen, sulfur dan oksigen yang relatif sama untuk setiap perconto teranalisis. Unsur karbon berkisar $57,03 \%$ s.d. $62,22 \%$, yang menunjukkan bahwa gambut mempunyai unsur karbon relatif $\leq 60 \%$. Selain itu, unsur oksigen mempunyai nilai yang relatif tinggi berkisar $30,78 \%$ s.d. $35,55 \%$ yang mengindikasikan bahwa gambut mempunyai kandungan unsur hara dan oksigen yang relatif tinggi.

\section{Analisis Petrografi Gambut}

Hasil analisis petrografi organik (Tabel 5) meliputi pengukuran nilai reflektansi vitrinit, komposisi maseral dan mineral.

Hasil pengukuran reflektansi vitrinit rata\% s.d. rata (random) perconto teranalisis berkisar $0,07 \%$ s.d. $0,17 \%$, Pengukuran reflektansi vitrinit sebagian besar dilakukan sebanyak 100 kali dengan nilai standar deviasi berkisar $0,02 \%$ s.d. 0,04 .

Tabel 3. Hasil analisis proksimat gambut di daerah penelitian

\begin{tabular}{|c|c|c|c|c|c|c|c|c|c|c|}
\hline \multirow[b]{2}{*}{$\begin{array}{c}\text { Kode } \\
\text { Perconto }\end{array}$} & \multicolumn{10}{|c|}{ Parameter Analisis } \\
\hline & $\begin{array}{c}\text { Air } \\
\text { bebas, } \\
\%(a r)\end{array}$ & $\begin{array}{l}\text { Air } \\
\text { total, } \\
\%(a r)\end{array}$ & $\begin{array}{c}\text { Air, } \\
\% \\
\text { (adb) }\end{array}$ & $\begin{array}{c}\text { Zat } \\
\text { terbang, } \\
\% \\
\text { (adb) }\end{array}$ & $\begin{array}{c}\text { Karbon } \\
\text { tertam } \\
\text { bat, \% } \\
\text { (adb) }\end{array}$ & $\begin{array}{c}\text { Abu, } \\
\% \\
\text { (adb) }\end{array}$ & $\begin{array}{c}\text { Sulfur } \\
\text { total, \% } \\
\text { (adb) }\end{array}$ & pH & $\begin{array}{c}\text { Densitas } \\
\mathrm{m}^{3} / \text { ton }\end{array}$ & $\begin{array}{c}\text { Nilai } \\
\text { kalori, } \\
\text { kal/g } \\
\text { (adb) }\end{array}$ \\
\hline GT-01 & 83,67 & 85,09 & 8,67 & 59,10 & 29,56 & 2,67 & 0,24 & 4,22 & 0,17 & 5.178 \\
\hline GT-02 & 86,01 & 87,28 & 9,10 & 53,71 & 27,80 & 9,39 & 0,67 & 4,42 & 0,13 & 4.580 \\
\hline GT-03 & 86,71 & 87,76 & 7,91 & 51,46 & 22,91 & 17,72 & 0,43 & 4,04 & 0,12 & 4.382 \\
\hline GT-05 & 88,46 & 89,72 & 10,90 & 52,01 & 27,03 & 10,06 & 0,37 & 4,63 & 0,10 & 4.452 \\
\hline GT-06 & 87,82 & 89,26 & 11,80 & 55,31 & 30,19 & 2,70 & 0,34 & 4,20 & 0,10 & 4.823 \\
\hline GT-07 & 86,53 & 87,99 & 10,86 & 55,41 & 29,19 & 4,54 & 0,30 & 4,00 & 0,12 & 4.767 \\
\hline GT-13 & 87,86 & 89,06 & 9,87 & 57,70 & 31,14 & 1,29 & 0,24 & 6,30 & 0,11 & 5.099 \\
\hline GTB-04 & 86,30 & 87,73 & 10,43 & 57,54 & 30,44 & 1,59 & 0,19 & 4,23 & 0,11 & 5.004 \\
\hline GTB-05 & 83,72 & 84,96 & 7,63 & 38,76 & 15,76 & 37,85 & 0,85 & 5,03 & 0,14 & 3.098 \\
\hline GTB-09 & 84,60 & 86,20 & 10,38 & 57,30 & 30,93 & 1,39 & 0,22 & 3,97 & 0,14 & 5.053 \\
\hline GTB-10 & 87,47 & 88,77 & 10,40 & 56,44 & 30,84 & 2,32 & 0,38 & 3,95 & 0,11 & 4.922 \\
\hline GTC-03 & 81,30 & 83,83 & 13,55 & 46,52 & 23,56 & 16,37 & 1,03 & 3,54 & 0,17 & 3.933 \\
\hline GTC-04 & 85,48 & 86,10 & 10,46 & 56,69 & 30,59 & 2,26 & 0,31 & 3,88 & 0,14 & 5.017 \\
\hline GTC-05 & 87,13 & 88,51 & 10,70 & 54,33 & 30,57 & 4,40 & 0,22 & 3,61 & 0,13 & 4.796 \\
\hline GTC-06 & 88,33 & 89,61 & 10,99 & 57,09 & 29,78 & 2,14 & 0,43 & 3,84 & 0,13 & 4.921 \\
\hline GTC-07 & 83,32 & 84,89 & 9,42 & 43,06 & 21,71 & 25,81 & 0,75 & 4,13 & 0,19 & 3.619 \\
\hline GTC-08 & 86,47 & 87,88 & 10,42 & 57,22 & 31,22 & 1,14 & 0,20 & 4,16 & 0,12 & 5.001 \\
\hline
\end{tabular}




\section{MAKALAH ILMIAH}

Tabel 4. Hasil analisis ultimat gambut di daerah penelitian.

\begin{tabular}{cccccc}
\hline \multirow{2}{*}{ Kode Perconto } & \multicolumn{5}{c}{ Parameter Analisis } \\
\cline { 2 - 6 } & Karbon, \% (daf) & Hidrogen, \% (daf) & Nitrogen, \%(daf) & Sulfur, \% (daf) & Oksigen, \% (daf) \\
\hline GT-01 & 62,22 & 5,50 & 1,22 & 0,27 & 30,78 \\
\hline GT-02 & 57,84 & 5,06 & 1,20 & 0,82 & 35,09 \\
\hline GT-03 & 59,42 & 5,73 & 1,24 & 0,58 & 33,03 \\
\hline GT-05 & 57,79 & 5,06 & 1,13 & 0,47 & 35,55 \\
\hline GT-06 & 59,51 & 4,89 & 0,99 & 0,39 & 34,21 \\
\hline GT-07 & 58,92 & 5,02 & 1,23 & 0,36 & 34,14 \\
\hline GT-13 & 59,71 & 4,96 & 0,92 & 0,27 & 33,80 \\
\hline GTB-04 & 59,99 & 5,00 & 0,99 & 0,22 & 35,24 \\
\hline GTB-05 & 55,91 & 5,95 & 1,34 & 1,56 & 34,25 \\
\hline GTB-09 & 59,70 & 4,87 & 0,92 & 0,25 & 34,66 \\
\hline GTB-10 & 59,07 & 4,87 & 0,96 & 0,44 & 34,11 \\
\hline GTC-03 & 58,25 & 5,14 & 1,03 & 1,46 & 33,50 \\
\hline GTC-04 & 60,15 & 5,02 & 0,97 & 0,36 & 34,65 \\
\hline GTC-05 & 59,31 & 4,91 & 0,87 & 0,26 & 34,33 \\
\hline GTC-06 & 59,14 & 0,98 & 0,50 & 35,31 \\
\hline GTC-07 & 57,03 & 5,05 & 1,10 & 1,16 & 34,57 \\
\hline GTC-08 & 59,47 & 5,40 & 0,85 & 0,23 & \\
\hline
\end{tabular}

Tabel 5. Hasil pengukuran reflektansi vitrinit dan komposisi kelompok maseral serta bahan mineral gambut di daerah penelitian.

\begin{tabular}{cccc}
\hline \multirow{2}{*}{ Kode Perconto } & \multicolumn{4}{c}{ Parameter Analisis } \\
\cline { 2 - 4 } & Nilai Rata-Rata Vitrinit Reflektansi (\% Rv Random) & Kisaran & Standar Deviasi \\
\hline GT-01 & 0,07 & $0,02-0,13$ & 0,03 \\
\hline GT-02 & 0,09 & $0,05-0,13$ & 0,02 \\
\hline GT-03 & 0,08 & $0,00-0,15$ & 0,04 \\
\hline GT-05 & 0,12 & $0,07-0,17$ & 0,02 \\
\hline GT-06 & 0,15 & $0,06-0,22$ & 0,04 \\
\hline GT-07 & 0,10 & $0,05-0,18$ & 0,02 \\
\hline GT-13 & 0,07 & $0,03-0,12$ & 0,02 \\
\hline GTB-04 & - & - & - \\
\hline GTB-05 & 0,10 & $0,04-0,17$ & 0,03 \\
\hline GTB-09 & - & - & - \\
\hline GTB-10 & 0,17 & $0,10-0,23$ & 0,04 \\
\hline GTC-03 & 0,14 & $0,07-0,19$ & 0,03 \\
\hline GTC-04 & 0,10 & 0,02 \\
\hline GTC-05 & 0,11 & $0,07-0,14$ & 0,03 \\
\hline GTC-06 & 0,10 & $0,04-0,18$ & 0,02 \\
\hline GTC-07 & 0,08 & $0,06-0,14$ & 0,03 \\
\hline GTC-08 & 0,12 & $0,03-0,14$ & 0,02 \\
\hline
\end{tabular}

Pengukuran komposisi maseral perconto gambut hanya dilakukan terhadap 7 perconto gambut di daerah penelitian. Hasil pengukuran tersebut menunjukkan bahwa material organik dalam seluruh perconto teranalisis didominasi oleh dua kelompok maseral, yaitu huminit dan inertinit. Komposisi huminit berkisar $38,43 \%$ s.d. $48,98 \%$ (Gambar 3a), sedangkan inertinit berkisar $24,84 \%$ s.d. 46,56\% (Gambar 3b). Komposisi kelompok maseral liptinit hanya berkisar $9,00 \%$ s.d. 21,48\% (Gambar 3b) (Tabel 6).
Komposisi huminit terdiri atas subkelompok maseral humotelinit berkisar $9,52 \%$ s.d. $17,52 \%$, humodetrinit $17,00 \%$ s.d. $25,50 \%$, dan humokolinit $5,15 \%$ s.d. $12,67 \%$. Komposisi inertinit meliputi subkelompok telo\% s.d. inertinit berkisar $20,81 \%$ s.d. $34,00 \%$, detro\% s.d. inertinit berkisar $3,36 \%$ s.d. $10,54 \%$, dan gelo $\%$ s.d. inertinit berkisar $0,00 \%$ s.d. $2,34 \%$, sedangkan komposisi liptinit hanya terdiri atas resinit berkisar $3,17 \%$ s.d. $17,11 \%$, kutinit berkisar $1,00 \%$ s.d. $3,44 \%$, sporinit berkisar $0,70 \%$ s.d. 3,78\%, liptodetrinit berkisar $0,00 \%$ s.d. $1,06 \%$, dan eksudatinit berkisar $1,36 \%$ s.d. $1,72 \%$. 


\section{MAKALAH ILMIAH}

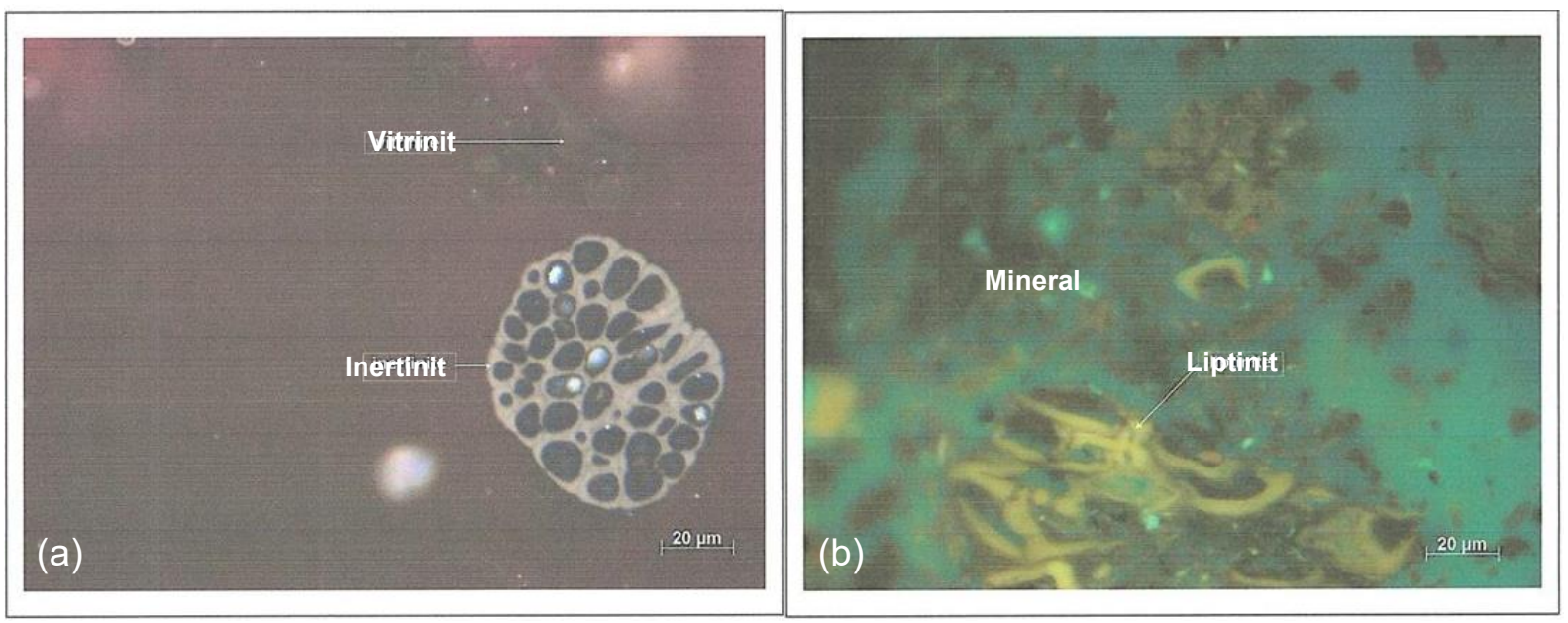

Gambar 3. (a) vitrinit/huminit dan inertinit pada perontoh GT-07, (b) Liptinit pada perconto GTC-08

Tabel 6. Komposisi maseral gambut di daerah penelitian

\begin{tabular}{|c|c|c|c|c|c|c|c|}
\hline Komposisi Petrografi & & & & e Samp & & & \\
\hline Maseral (Vol. \%) & GT-01 & GT-02 & GT-03 & GT-05 & GT-06 & GT-07 & GT-13 \\
\hline Tekstinit & 7,48 & 9,73 & 10,65 & 9,00 & 10,03 & 11,97 & 9,67 \\
\hline Ulminit & 2,04 & 4,36 & 6,87 & 5,67 & 5,35 & 4,93 & 5,00 \\
\hline (Total Humotelinit) & 9,52 & 14,09 & 17,52 & 14,67 & 15,38 & 16,90 & 14,67 \\
\hline Atrinit & 18,37 & 25,50 & 18,21 & 17,00 & 24,75 & 25,35 & 23,67 \\
\hline Densinit & 0,00 & 0,00 & 0,00 & 0,00 & 0,00 & 0,00 & 0,00 \\
\hline (Total Humodetrinit) & 18,37 & 25,50 & 18,21 & 17,00 & 24,75 & 25,35 & 23,67 \\
\hline Korpohuminit & 7,82 & 7,38 & 4,12 & 9,67 & 6,02 & 4,58 & 5,00 \\
\hline Gelinit & 2,72 & 2,01 & 1,03 & 3,00 & 1,00 & 1,06 & 2,33 \\
\hline (Total Humokolinit) & 10,54 & 9,39 & 5,15 & 12,67 & 7,02 & 5,64 & 7,33 \\
\hline Total Huminit & 38,43 & 48,98 & 40,88 & 44,34 & 47,15 & 47,89 & 45,67 \\
\hline Fusinit & 15,65 & 11,41 & 10,65 & 23,00 & 17,06 & 11,27 & 8,33 \\
\hline Semifusinit & 14,29 & 5,37 & 8,25 & 10,00 & 15,72 & 8,45 & 7,33 \\
\hline Funginit & 3,74 & 4,03 & 2,06 & 1,00 & 0,00 & 1,76 & 8,33 \\
\hline (Total Telo-inertinit) & 33,68 & 20,81 & 20,96 & 34,00 & 32,78 & 21,48 & 23,99 \\
\hline Inertodetrinit & 10,54 & 3,36 & 9,62 & 5,00 & 6,69 & 4,23 & 4,00 \\
\hline Mikrinit & 0,00 & 0,00 & 0,00 & 0,00 & 0,00 & 0,00 & 0,00 \\
\hline (Total Detro-inertinit) & 10,54 & 3,36 & 9,62 & 5,00 & 6,69 & 4,23 & 4,00 \\
\hline Skelrotinit & 2,00 & 0,00 & 0,00 & 0,00 & 0,33 & 0,00 & 0,00 \\
\hline Makrinit & 0,34 & 0,67 & 1,38 & 0,67 & 0,00 & 0,00 & 0,67 \\
\hline (Total Geloinertinit) & 2,34 & 0,67 & 1,38 & 0,67 & 0,33 & 0,00 & 0,67 \\
\hline Total Inertinit & 46,56 & 24,84 & 31,96 & 39,67 & 39,80 & 25,71 & 28,66 \\
\hline Resinit & 7,82 & 17,11 & 7,22 & 8,67 & 7,02 & 3,17 & 3,67 \\
\hline Kutinit & 1,36 & 3,36 & 3,44 & 1,33 & 1,00 & 1,76 & 3,00 \\
\hline Sporinit & 2,38 & 1,01 & 3,78 & 0,33 & 0,67 & 0,70 & 2,33 \\
\hline Alginit & 0,00 & 0,00 & 0,00 & 0,00 & 0,00 & 0,00 & 0,00 \\
\hline Suberinit & 0,00 & 0,00 & 0,00 & 0,00 & 0,00 & 0,00 & 0,00 \\
\hline Liptodetrinit & 0,00 & 0,00 & 0,00 & 0,00 & 0,00 & 1,06 & 0,00 \\
\hline Eksudatinit & 1,36 & 0,00 & 1,72 & 0,00 & 0,00 & 0,00 & 0,00 \\
\hline Total Liptinit & 12,92 & 21,48 & 16,16 & 10,33 & 8,69 & 6,69 & 9,00 \\
\hline (Total Maseral) & $\mathbf{9 7 , 9 1}$ & 95,30 & 89,00 & 94,34 & 95,64 & 80,29 & 83,33 \\
\hline (Total Mineral) & 2,19 & 4,70 & 11,00 & 5,66 & 4,36 & 19,71 & 16,67 \\
\hline
\end{tabular}


Menurut Diessel (1992), lingkungan pengendapan atau tempat terbentuknya gambut dapat dibedakan menjadi 4 (empat), yaitu limnik, telmatik, payau, dan kaya akan kalsium. Lingkungan limnik menghasilkan lahan gambut yang terbentuk di bawah air rawa, sedangkan telmatik adalah lingkungan dengan batas air pada lahan gambut dipengaruhi oleh pasang surut air. Lingkungan payau dan kaya akan kalsium umumnya menghasilkan gambut yang kaya akan sulfur, abu, fosil laut, nitrogen, dan kalsium.

Diessel (1992) menyatakan bahwa indeks jaringan terawetkan (TPI) merupakan perbandingan antara struktur jaringan yang terawetkan dengan struktur jaringan yang tidak terawetkan, sedangkan indeks gelifikasi (GI) merupakan perbandingan antara material organik yang terbentuk akibat proses gelifikasi dengan material organik yang terbentuk karena proses oksidasi dan berhubungan dengan kontinuitas kelembapan pada suatu lahan gambut.

Derajat humifikasi yang terjadi pada lahan gambut dapat dibuktikan dengan nilai TPI dan GI. Nilai TPI dan GI dapat digunakan untuk menentukan lingkungan pengendapan dan perkiraan derajat dekomposisi gambut (Diessel, 1992).

Perhitungan nilai TPI dan GI gambut di daerah penelitian menggunakan persamaan TPI dan GI dari Diessel (1992) yang telah dimodifikasi oleh Amijaya dan Littke (2005) untuk klasifikasi batubara peringkat rendah (brown coal), sebagai berikut:

$\mathrm{TPI}=\frac{\text { Humotelinit }+ \text { Teloinertinit }}{\text { Humodetrinit }+ \text { Humokolinit }+ \text { Inertodetrinit }+ \text { Gelo-inertinit }}$

$\mathrm{GI}=\frac{\text { Huminit }+ \text { Gelo-inertinit }}{\text { Inertinit (kecuali Makrinit dan Sekretinit) }}$

Hasil perhitungan nilai TPI dan GI dengan menggunakan persamaan di atas dapat dilihat pada Tabel 7. Hasil perhitungan nilai TPI pada 7 (tujuh) perconto gambut di daerah penelitian memiliki nilai bervariasi, berkisar 1,04 s.d. 1,38 dengan nilai rata-rata 1,18. Pada umumnya, perhitungan nilai TPI setiap perconto gambut di daerah penelitian menunjukkan nilai yang relatif sama, sedangkan nilai GI untuk setiap perconto gambut berkisar 1,04-1,73, dengan nilai rata-rata 1,41.

Tabel 7. Hasil perhitungan TPI dan GI di daerah penelitian.

\begin{tabular}{ccc}
\hline No. Perconto & TPI & GI \\
\hline GT-01 & 1,17 & 1,04 \\
\hline GT-02 & 1,04 & 1,72 \\
\hline GT-03 & 1,12 & 1,38 \\
\hline GT-05 & 1,38 & 1,15 \\
\hline GT-06 & 1,25 & 1,20 \\
\hline GT-07 & 1,21 & 1,73 \\
\hline GT-13 & 1,08 & 1,66 \\
\hline
\end{tabular}

Indeks air tanah (GWI) didefinisikan sebagai perbandingan antara jaringan dengan tingkat gelifikasi besar terhadap jaringan yang mengalami gelifikasi kecil. Nilai GWI digunakan untuk menunjukkan tingkat gelifikasi yang mengindikasikan keadaan $\mathrm{pH}$ dan suplai air pada suatu lahan gambut (Calder dkk., 1991).

Perhitungan nilai GWI dan VI gambut di daerah penelitian mengadopsi persamaan GWI dan VI dari Diessel (1992) yang telah dimodifikasi oleh Amijaya dan Littke (2005) untuk klasifikasi batubara peringkat rendah sebagai berikut:

$$
\text { GWI }=\frac{\text { Korpogelinit }+ \text { Material Mineral }}{\text { Telinit }+ \text { Kolotelinit }+ \text { Detrovitrinit }} \ldots \ldots . .(3)
$$

Indeks vegetasi (VI) digunakan sebagai petunjuk dalam menentukan asal pembentukan lahan gambut (Calder et al., 1991). Perhitungan nilai VI menggunakan persamaan sebagai berikut:

$\mathrm{VI}=\frac{\text { Telovitrinit }+ \text { Semifusinit }+ \text { Fusinit }+ \text { Suberinit }+ \text { Resinit }}{\text { Detrovitrinit }+ \text { Inertodetrinit }+ \text { Liptodetrinit }+ \text { Sporinit }+ \text { Kutinit }+ \text { Alginit }}$

Perhitungan nilai GWI dan VI tehadap 7 (tujuh) perconto gambut ditunjukkan pada Tabel 8. Berdasarkan hasil perhitungan GWI untuk setiap perconto gambut di daerah penelitian mempunyai nilai yang bervariasi berkisar antara 0,29-0,66 dengan nilai rata-rata 0,56 , sedangkan $\mathrm{VI}$ 
untuk setiap perconto tersebut menunjukkan berkisar 1,03-2,38 dengan nilai rata-rata 1,49 .

Tabel 8. Hasil perhitungan GWI dan VI di daerah penelitian.

\begin{tabular}{ccc}
\hline No. Perconto & GWI & VI \\
\hline GT-01 & 0,63 & 1,55 \\
\hline GT-02 & 0,65 & 1,17 \\
\hline GT-03 & 0,45 & 1,25 \\
\hline GT-05 & 0,58 & 2,38 \\
\hline GT-06 & 0,29 & 1,67 \\
\hline GT-07 & 0,66 & 1,40 \\
\hline GT-13 & 0,63 & 1,03 \\
\hline
\end{tabular}

\section{PEMBAHASAN}

\section{Karakteristik Gambut}

Kenampakan megaskopis gambut di daerah penelitian sebagai berikut:

Warna, warna endapan gambut yang terdapat dekat permukaan, setempat dijumpai berwarna cokelat muda sampai kehitaman. Warna hitam diperkirakan karena pengaruh dari terbakarnya material pembentuk gambut di permukaan, derajat pembusukan, dan kandungan zat organik.

Derajat pembusukan $(\mathbf{H})$, derajat pembusukan gambut di daerah penelitian menurut skala van Post berkisar $\mathrm{H} 3-\mathrm{H} 5$ (gambut yang mengalami pembusukan rendah-sedang) dan mempunyai tipe hemik dengan kandungan serat $38 \%$ s.d. $45 \%$.

Kandungan kayu (W), kandungan kayu dalam gambut di daerah penelitian berkisar $5 \%$ s.d. $10 \%$.

Kandungan akar (R), kandungan akar dalam gambut di daerah penelitian berkisar $10 \%$ s.d. $15 \%$.

Kandungan daun, kandungan daun dari gambut tersebut berkisar $5 \%$ s.d. $7 \%$.

Kandungan air (M), kondisi kandungan air atau kelembapan gambut agak kering. Hal tersebut menunjukkan gambut di daerah penelitian mempunyai drainase dan berada di atas muka air tanah.

Hasil analisis proksimat terhadap seluruh perconto gambut di daerah penelitian menunjukkan bahwa kandungan abu akan memengaruhi nilai kalori gambut. Kandungan abu yang relatif tinggi akan menurunkan nilai kalori gambut, demikian pula sebaliknya. Sebagai contoh, pada perconto gambut GTB-05 mempunyai kandungan abu paling tinggi, yaitu $37,85 \%$, hanya mempunyai nilai kalori $3.098 \mathrm{kal} / \mathrm{g}$ (Gambar 4).

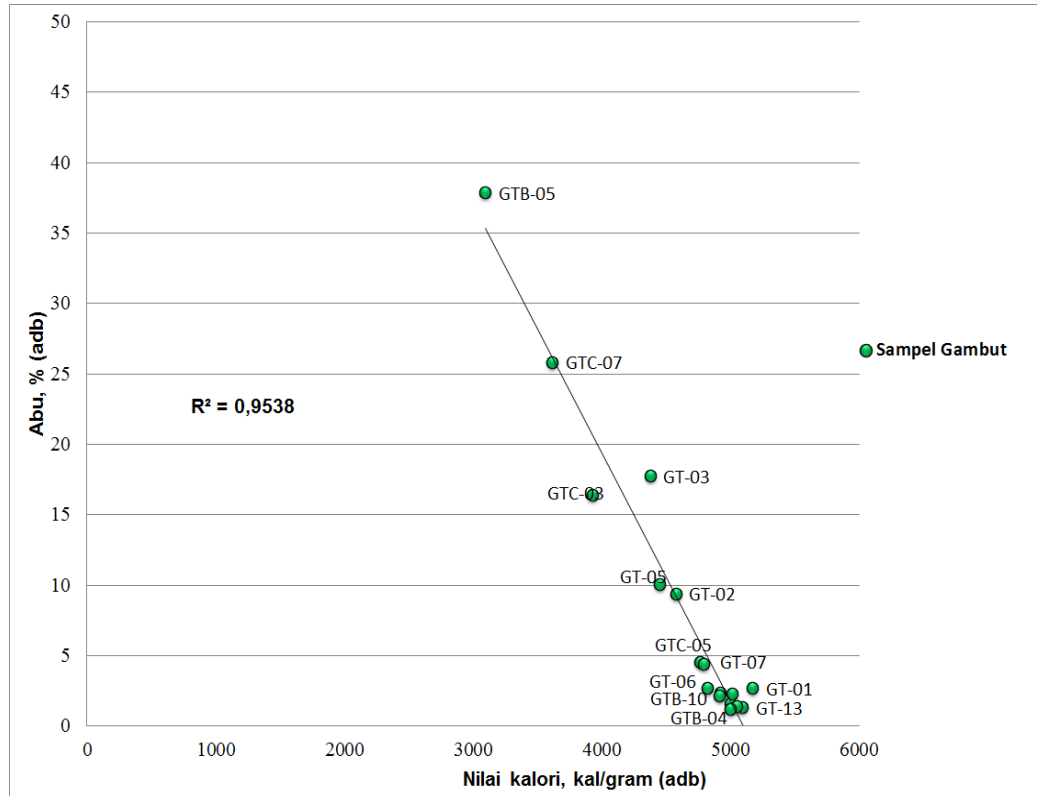

Gambar 4. Plot nilai kalor terhadap kadar abu perconto gambut di daerah penelitian 
Berdasarkan klasifikasi ASTM, diketahui bahwa gambut mempunyai nilai reflektansi vitrinit berkisar $0,00 \%$ s.d. $0,23 \%$ dan kandungan zat terbang dalam daf berkisar $65 \%$ s.d. $70 \%$. Hasil analisis menunjukkan bahwa perconto gambut di daerah penelitian mempunyai nilai reflektansi vitrinit berkisar $0,07 \%$ s.d. $0,15 \%$ dan kandungan zat terbang $64 \%$ s.d. $71 \%$ yang menunjukkan bahwa seluruh perconto teranalisis termasuk dalam peringkat gambut (Gambar 5).

Kandungan $\mathrm{pH}$ seluruh perconto teranalisis berkisar 3,54 s.d. 5,03 (Tabel 3) yang menunjukkan bahwa gambut di daerah penelitian bersifat asam $(<7)$ yang mengindikasikan tipe gambut ombrotropik atau ombrogenus (Moore, 1987). Selain itu, berdasarkan hasil analisis, komposisi kelompok maseral didominasi oleh huminit yang mengindikasikan bahwa gambut di daerah penelitian terbentuk di lingkungan rawa hutan basah (wet forest swamp) (Diessel, 1992).

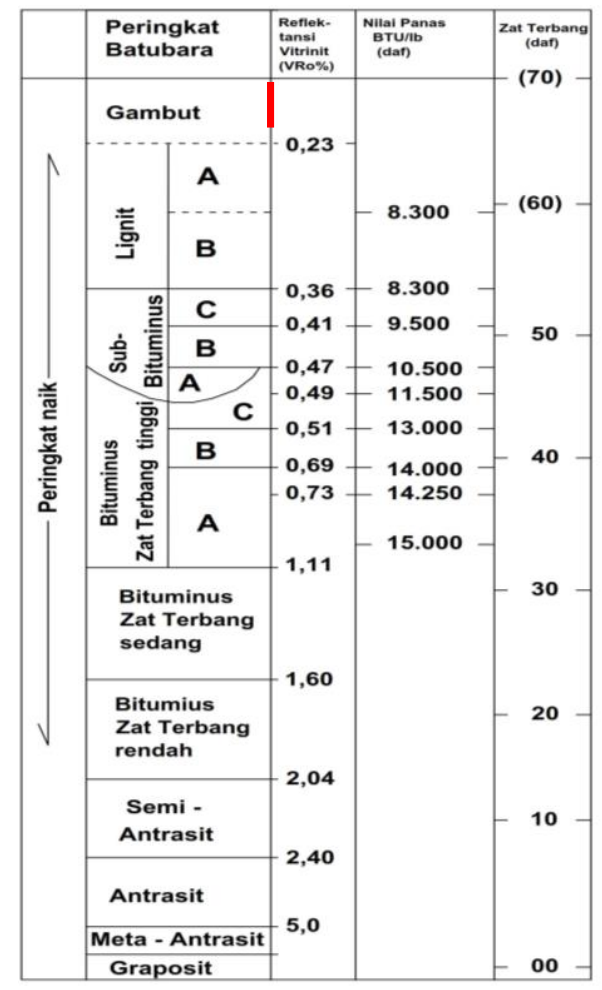

Gambar 5. Peringkat perconto teranalisis berdasarkan klasifikasi ASTM (1986)
Hasil plot silang antara nilai TPI dan GI dalam diagram Lamberson dkk. (1991) mengindikasikan bahwa seluruh perconto gambut di daerah penelitian diendapkan pada lingkungan rawa hutan basah dengan kondisi gambut yang dipengaruhi oleh pasang surut air (Gambar 6). Lingkungan pengendapan telmatik menghasilkan suatu lahan gambut yang tumbuh secara in-situ dan tidak terganggu oleh endapan sedimen lain (Diessel, 1992).

Calder dkk., (1991) menjelaskan bahwa apabila nilai GWI $<1,00$ mengindikasikan lingkungan purba pembentuk gambut terjadi pada kondisi telmatik, sedangkan nilai $\mathrm{Vl}<3,00$ mengisyaratkan tetumbuhan yang tumbuh pada lahan gambut berasal dari tetumbuhan berbatang lunak (herbaceous atau marginal aquatic). Nilai $\mathrm{VI}>3,00$ mengindikasikan tetumbuhan yang tumbuh pada lahan gambut berasal dari tetumbuhan kayu. Komposisi subkelompok maseral yang terdapat pada tumbuhan kayu umumnya didominasi oleh humotelinit, sedangkan humodetrinit didominasi oleh tumbuhan berbatang lunak.

Hasil perhitungan nilai GWI pada gambut di daerah penelitian menunjukkan nilai rata-rata 0,55 yang mengindikasikan bahwa gambut terbentuk pada kondisi lingkungan telmatik. Nilai GWI yang rendah juga mengindikasikan keadaan lingkungan bog, dengan tipe gambut ombrotropik atau ombrogenus (Gambar 7). Lingkungan tersebut mempunyai ciri berupa batas air berada di bawah permukaan gambut dengan nutrisi hanya berasal dari air hujan. Umumnya, gambut yang terbentuk pada lingkungan ini mempunyai suplai nutrisi yang rendah dan bersifat asam. Selain itu, berdasarkan nilai VI menunjukkan bahwa seluruh tetumbuhan yang tumbuh pada lahan gambut berasal dari tumbuhan berbatang lunak (Gambar 7). 


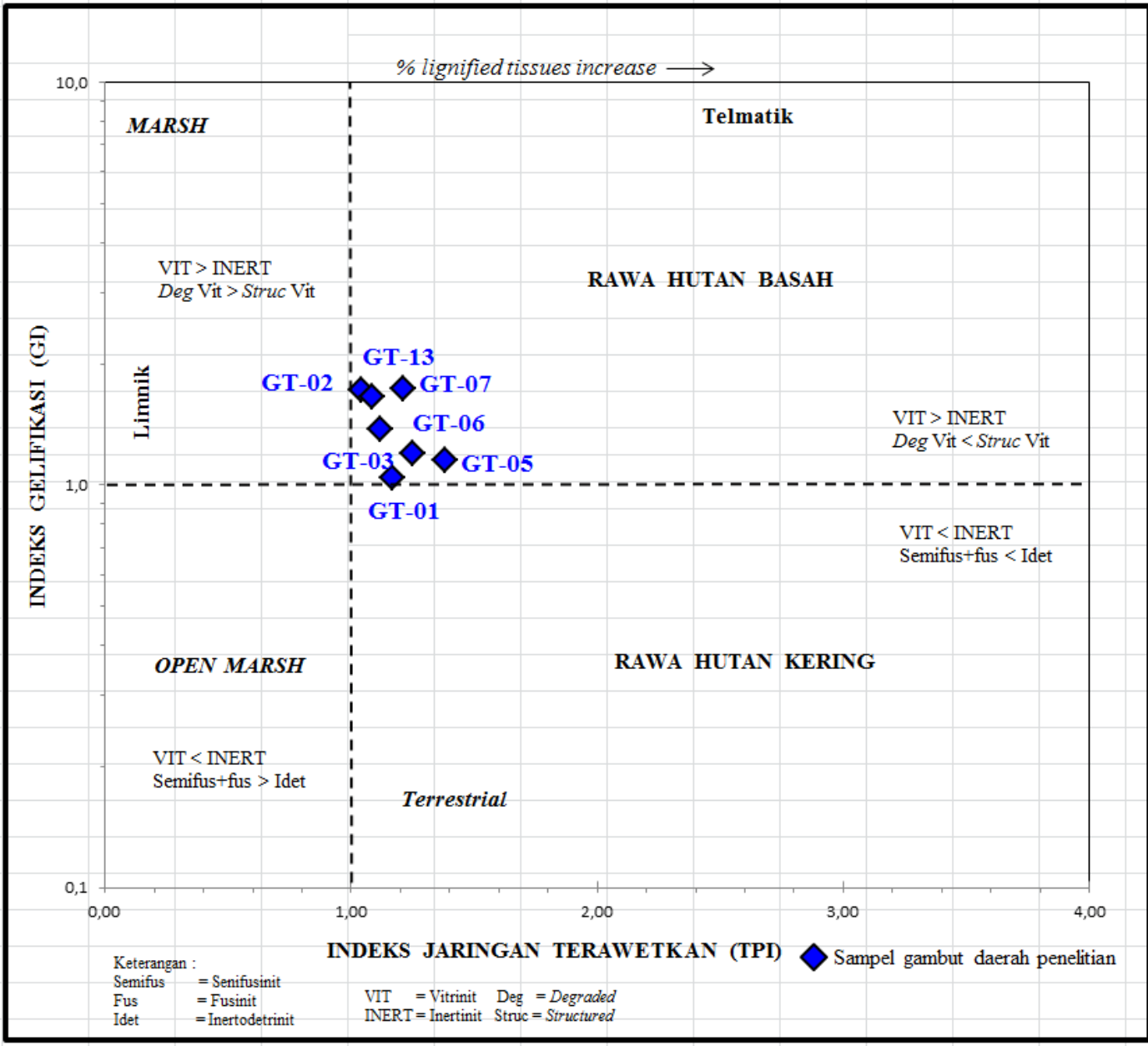

Gambar 6. Plot silang nilai TPI dan GI perconto gambut di daerah penelitian.

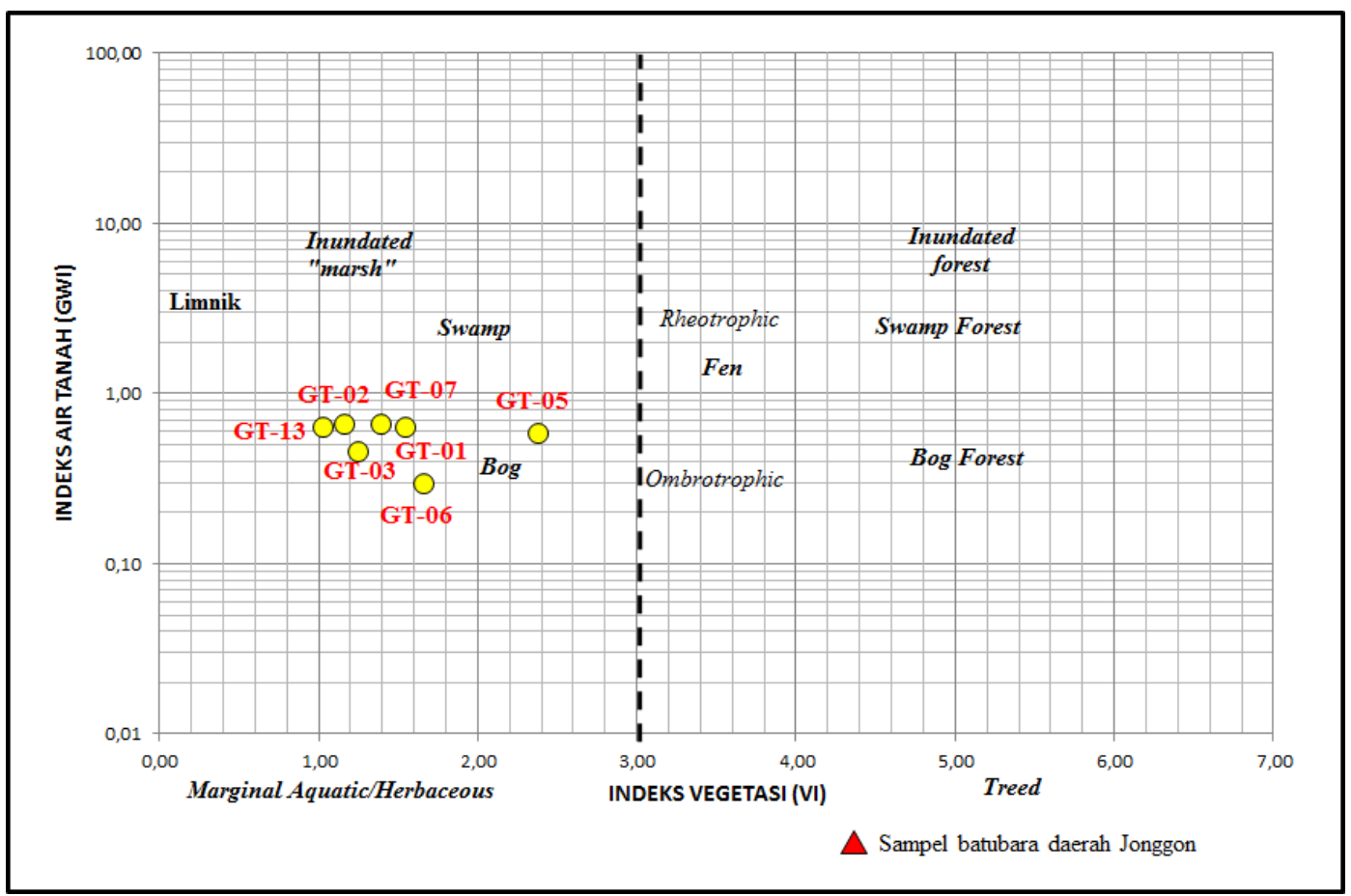

Gambar 7. Plot silang nilai VI terhadap GWI perconto gambut di daerah penelitian 


\section{MAKALAH ILMIAH}

\section{KESIMPULAN}

Hasil analisis geokimia dan petrografi organik menunjukkan bahwa gambut di daerah penelitian (Gambar 8) mempunyai nilai kalori $3.098 \mathrm{kal} / \mathrm{g}$ s.d. $5.178 \mathrm{kal} / \mathrm{g}$ dengan Reflektan Vitrinit berkisar 0,07\% s.d. $0,17 \%$., sedangkan hasil analisis komposisi maseral didominasi oleh huminit yang mengindikasikan bahwa gambut di daerah penelitian terbentuk di lingkungan rawa hutan basah.
Berdasarkan plot silang antara nilai TPI dan GI menunjukkan bahwa gambut di daerah penelitian diendapkan pada lingkungan rawa hutan basah dengan kondisi gambut yang dipengaruhi oleh pasang surut air, sedangkan hasil plot silang antara nilai GWI dan VI menunjukkan bahwa gambut di daerah penelitian terbentuk pada lingkungan bog bertipe ombrotropik atau ombrogenus dan tetumbuhan yang membentuk gambut merupakan tumbuhan berbatang lunak dengan kondisi gambut yang dipengaruhi oleh pasang surut air.

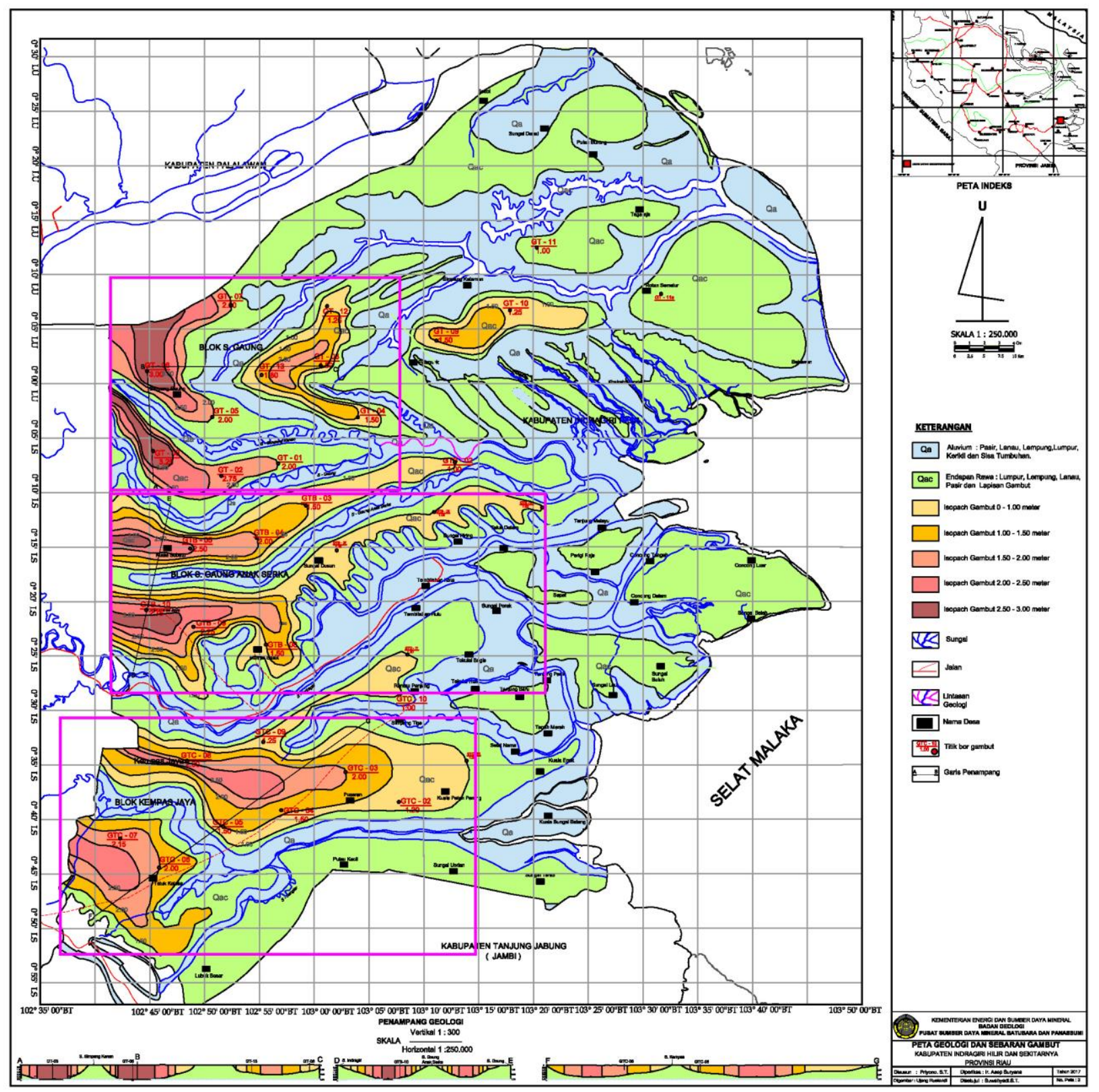

Gambar 8. Peta geologi dan sebaran gambut di daerah penelitian 


\section{UCAPAN TERIMA KASIH}

Ucapan terima kasih penulis sampaikan kepada instansi Pusat Sumber Daya Mineral, Batubara dan Panas Bumi, Badan Geologi, Kementerian Energi dan Sumber Daya Mineral yang telah membantu dalam pembiayaan kegiatan penelitian ini. Selain itu, penulis juga mengucapkan terima kasih kepada Ir. Asep Suryana yang telah mendukung penulis dalam pembuatan makalah ini. Penulis mengucapkan terima kasih pula kepada Fatih Akbarul Irsan yang telah membantu penulis dalam kegiatan penelitian di laboratorium dan segenap rekan di Bidang Batubara yang telah memberikan dukungan, sehingga makalah ini dapat terselesaikan.

\section{DAFTAR PUSTAKA}

Agus, F. dan Subiksa, I.G.M. (2008): Lahan gambut: potensi untuk pertanian dan aspek lingkungan. Balai Penelitian Tanah dan World Agroforestry Centre (ICRAF), Bogor, Indonesia.

Amijaya, H. and Littke, R. (2005): Microfasies and depositional environment of Tertiary Tanjung Enim low rank coal, South Sumatera Basin, Indonesia. International Journal of Coal Geology, vol. 61, p. 197-221.

Anggayana, K. (2002): Diktat kuliah genesa batubara, Departemen Teknik Pertambangan, ITB.

ASTM (1986): Annual book of ASTM standards, American Society for Testing and Materials, Philadelphia, 388, PA.

Calder, J.H., Gibling, M.R., and Mukopadhyay, P.K. (1991): Peat formation in a Westphalian B piedmont setting, Cumberland Basin, Nova Scotia: implications for the maceral-based interpretation of rheotrohic and raised paleo-mires: Bulletin de la Socie'te' Ge'ologique de France, 162/2, 283-298.
Chou, C.L. (2012): Sulfur in coals: A review of geochemistry and origins. International Journal of Coal Geology, vol. 100, p. 1-13.

Cook, A.C. (1982): The Origin and Petrology of Organic Matter in Coal, Oil Shales and Petroleum Source Rocks, University of Wollongong, Wollongong,

de Coster, G.L. (1974): The Geology of The Central and South Sumatra Basins, Proceedings Indonesian Petroleum Association, $3^{\text {rd }}$ Annual Convention.

Diessel, C.F.K. (1992): Coal-bearing depositional systems, Springer-Verlag, Berlin, Heidelberg.

Lamberson, M.N., Bustin, R.M., dan Kalkreuth, W. (1991): Lithotype (maceral) composition and variation as correlated with paleowetland environments, Gates Formations, Northeastern British Columbia. Canada; International Journal of Coal Geology, vol. 18, p. 87-124.

Moore, P.D. (1987): Ecological and hydrological aspects of peat formation, dalam Scott A., C. (editor) Coal and coal-bearing strata, recent advances, Geol. Soc. Am. Spec. Publ., vol. 32, p. 7-15.

Ritung, S., Wahyunto, Nugroho, K., Sukarman, Hikmatullah, Suparto, dan Tafakresnanto, C. (2011): Peta Lahan Gambut Indonesia Skala 1:250.000, Badan Balai Besar Penelitian dan Pengembangan Sumberdaya Lahan Pertanian, Kementrian Pertanian.

Stach, E., Mackowsky, M.Th., Teichmuller, M., Taylor, G.H., Chandra, D., dan Teichmuller, R. (1982): Stach's textbook of coal petrology, Gebruder, Borntraeger, Berlin, $535 \mathrm{p}$.

Suwarna, N., Budhitrisna, T., Santosa, S., dan Mangga, A. (1995): Peta Geologi Lembar Rengat, Sumatra, P3G, Bandung. 